\title{
PERMAINAN TRADISIONAL, ALTERNATIF MEDIA PENGEMBANGAN KOMPETENSI SOSIAL-EMOSI ANAK USIA DINI
}

\author{
Nurul Afrianti ${ }^{1}$
}

\begin{abstract}
ABSTRAK
Kompetensi sosial memiliki dampak positif pada perkembangan anak. Kompetensi sosial mendukung kemampuan komunikasi, keberhasilan akademik dan adaptasi di sekolah, serta memperkuat hubungan sebaya dan menciptakan lingkungan yang positif dalam pembelajaran. Oleh sebab itu, kompetensi ini harus dikembangkan sejak dini secara optimal. Salah satu cara mengembangan kompetensi sosial emosional pada naka usia dini adalah melalui permainan tradisonal. Terdapat beragam jenis permainan tradisonal yang dapat digunakan sebagai media alternatif pegnembangan sosial emosional anak usia diini.

Kata Kunci: Permainan Tradisional, Media Pembelajaran, Sosial Emsional Anak
\end{abstract}

\section{A. PENDAHULUAN}

Pendidikan merupakan modal dasar untuk menyiapkan insan yang berkualitas. Menurut Undang-undang Sisdiknas Pendidikan adalah usaha sadar dan terencana untuk mewujudkan suasana belajar dan proses pembelajaran agar peserta didik secara aktif mengembangkan potensi dirinya untuk memiliki kekuatan spiritual keagamaan, pengendalian diri, kepribadian, kecerdasan, akhlak mulia, serta keterampilan yang diperlukan dirinya, masyarakat, bangsa dan negara. Menurut UNESCO pendidikan hendaknya dibangun dengan empat pilar, yaitu learning to know, learning to do, learning to be, dan learning to live together.

Pada hakikatnya belajar harus berlangsung sepanjang hayat. Untuk menciptakan generasi yang berkualitas, pendidikan harus dilakukan sejak usia dini dalam hal ini melalui Pendidikan Anak Usia Dini (PAUD), yaitu pendidikan yang ditujukan bagi anak sejak lahir hingga usia 6 tahun. Sejak dipublikasikannya hasilhasil riset mutakhir di bidang neuroscience dan psikologi maka fenomena pentingnya PAUD merupakan keniscayaan. PAUD menjadi sangat penting mengingat potensi kecerdasan dan dasar-dasar perilaku seseorang terbentuk pada rentang usia ini. Sedemikian pentingnya masa ini sehingga usia dini sering disebut the golden age (usia emas).

PAUD di atur dengan jelas dalam UU No.20 Th 2003 tentang Sisdiknas sebagai jenjang pendidikan dan jalur pendidikan memiliki kurikulum yang sama baik pada PAUD Formal maupun Nonformal. Sebagai jenjang pendidikan, PAUD merupakan pendidikan yang diselenggarakan sebelum pendidikan dasar sembilan tahun. Hal tersebut bertujuan menyiapkan anak-anak usia dini siap memasuki jalur pendidikan dasar selanjutnya dengan bekal kesiapan mental dan emosional serta aspek-aspek lain dalam diri anak untuk menerima beban materi yang lebih di tingkat pendidikan dasar.

${ }^{1}$ Dosen PGPAUD Fakultas Tarbiyah dan Keguruan, Universitas Islam Bandung 
Kesempatan pendidikan yang diberikan kepada anak-anak di usia prasekolah tidak hanya mendukung perkembangan anak, tetapi juga memberikan kontribusi positif untuk hubungan antara orang tua dan anak. Selama bertahun-tahun, beberapa penelitian yang dilakukan pada berbagai kelompok sampel menunjukkan bahwa pendidikan prasekolah memberikan kontribusi bagi perkembangan kognitif, emosional, sosial dan fisik anak serta keluarga (Horn et al 2005.; Huffman, Mehlinger dan Kerivan, 2000; Jalongo et al. 2004; Pianta et al. 2002; Ramey dan Ramey, 1998; Ramey et al. 2000; Tesser dan Iedema, 2001). Pendidikan prasekolah mendukung perkembangan anak, dan berkontribusi terhadap pembentukan perilaku positif dalam konteks ini adalah kompetensi sosial. Kompetensi sosial memiliki peranan penting dalam kehidupan anak. Anak yang memiliki kompetensi sosial cenderung lebih mudah untuk bergaul, bermain, dan menyesuaikan diri. Sebaliknya, anak yang tidak memiliki kompetensi sosial cenderung mengalami kesulitan berhubungan secara sosial dengan teman sebaya. Padahal kemampuan anak untuk berhubungan sosial dengan lingkungan sudah dimulai sejak lahir.

Kompetensi sosial memiliki dampak positif pada perkembangan anak. Kompetensi sosial mendukung kemampuan komunikasi, keberhasilan akademik dan adaptasi di sekolah, serta memperkuat hubungan sebaya dan menciptakan lingkungan yang positif dalam pembelajaran (Akman, 2009; Kemp dan Carter, 2005). Selain itu, kompetensi sosial juga membantu anak untuk mengembangkan persepsi positif tentang diri dan orang lain. Anak yang tidak memiliki kompetensi sosial dapat memiliki masalah adaptasi sekolah dan penerimaan teman sebaya, dan lebih rentan terhadap kenakalan serta putus sekolah. Kompetensi sosial yang mulai berkembang saat interaksi ibu-anak tepat setelah kelahiran, memainkan peran penting dalam perkembangan sosial anak usia prasekolah. Oleh karena itu, keterampilan ini dapat mempengaruhi perkembangan sosial dalam jangka pendek dan jangka panjang.

Individu dengan kompetensi sosial yang baik dapat berhasil dalam semua jenis kegiatan yang memerlukan interaksi dengan orang lain (Karayılmaz, 2008). Kompetensi sosial yang berkembang dengan baik memiliki peran yang menentukan dalam membentuk hubungan sosial individu. Sebagai contoh, individu yang memiliki kompetensi sosial akan mampu mempengaruhi perilaku teman-temannya selama periode prasekolah (Gulay, 2009).

Penelitian Schaps (dalam Goleman, 1997) yang dilakukan di Taman Kanakkanak hingga Sekolah Dasar kelas 6 di Northern California, menunjukkan bahwa anak-anak yang memiliki keterampilan sosial lebih mudah diterima oleh lingkungan sosialnya. Anak-anak tersebut memiliki karakteristik: mampu bertanggung jawab, tegas, populer dan mudah bergaul, bersifat sosial dan suka menolong, memahami orang lain, tenggang rasa, penuh perhatian, terampil dalam menyelesaikan konflik, dan juga pintar dalam menerapkan starategi untuk menyelesaikan masalah antarpribadi. Anak yang tidak memiliki keterampilan sosial yang baik biasanya ditunjukkan dengan ketidakmampuan anak dalam menafsirkan atau menggunakan bahasa tubuh, seringkali salah paham atau keliru memanfaatkan ekspresi wajah misalnya gagal melakukan kontak mata, anak gugup bila harus melakukan percakapan ringan, tidak mengetahui kapan 
harus mengakhiri pembicaraan dan merasa takut bahwa apa yang dibicarakannya tidak dapat menarik minat orang lain.

Keterampilan sosial, diakui sebagai salah satu penentu kompetensi sosial, mempengaruhi adaptasi anak-anak terhadap lingkungan sosial (Anthony et al 2005; Cheah dan Rubin, 2004; Kogyigit dan Kayi 2008; Spegman dan Houck, 2005). Lembaga pendidikan prasekolah memberikan banyak kesempatan bagi anak untuk belajar dalam mengembangkan kompetensi sosial (Ekinci dan Gfir § im § ek, 2009). Anak-anak di usia prasekolah perlu mendapatkan kompetensi sosial seperti kerjasama, berbagi, membantu dan berpartisipasi dalam kelompok sebaya.

Bahkan menurut Bierman \& Furman (1984; dalam Matson \& Ollendick, 1988) anak yang tidak memiliki kompetensi sosial akan ditolak dalam lingkungan sosial. Beberapa penelitian longitudinal oleh Kagan dan Moss (1962; dalam Cartledge dan Milburn, 1992) mengindikasikan anak-anak yang mengalami ketidakmampuan dalam berinteraksi sosial dan tidak memperoleh bantuan, akan mengalami masalah sosial sampai dewasa. Akibat lain yang muncul apabila masalah sosial dibiarkan, anak akan mengalami perilaku maladaptive (Bierman \& Furman, 1984 dalam Matson \& Ollendick, 1988: 3).

Selain kompetensi sosial, emosi dan berperan penting dalam mempengaruhi hubungan sosial (Bayhan \& Artan, 2004; Karayılmaz, 2008), sebab emosi sangat penting dalam membimbing anak ketika berinteraksi dengan lingkungannya (Bayhan \& Artan, 2004; Karayılmaz, 2008). Perkembangan emosi merupakan dasar dari perkembangan sosial (Alpan, 2006; Kandır \& Alpan, 2008). Bahkan Bloom (1990) berpendapat bahwa salah satu faktor yang mempengaruhi kompetensi sosial adalah faktor personal yang meliputi regulasi emosi. Selain itu, penelitian terdahulu menunjukkan bahwa anak yang memiliki kompetensi sosial yang baik juga memiliki kemampuan regulasi emosi yang baik. Perkembangan sosial dan emosi memiliki peran yang signifikan dalam perkembangan kepribadian yang sehat dan dalam perkembangan interaksi positif dengan lingkungan (Alpan, 2006; Aral, Baran, Bulat, \& Cimen, 2001).

Pengembangan kompetensi sosial dan regulasi emosi harus menjadi sasaran pendidikan prasekolah. Guru prasekolah memiliki peran penting dalam menentukan masalah perilaku (Alisinanoglu \& Kesicioglu, 2010). Selain itu, lembaga pendidikan prasekolah (PAUD) memberi banyak kesempatan bagi anak untuk belajar dalam mengembangkan kompetensi sosial dan emosi (Ekinci dan Gfir § im § ek, 2009). Pendidikan prasekolah yang berkualitas baik akan memenuhi kebutuhan anak-anak dan mendukung perkembangan mereka. Penelitian yang relevan (Melhuish dan Lambidi, 1996) menunjukkan bahwa program pendidikan prasekolah yang berkualitas baik akan mempengaruhi emosi dan kompetensi sosial anak.

Program pendidikan prasekolah akan efektif dalam mengembangkan kompetensi sosial-emosi anak apabila diselenggarakan melalui penggunaan media yang efektif salah satunya melalui bermain dalam perspektif budaya atau permainan tradisional. Permainan tradisional dari sisi budaya merupakan identitias kebudayaan asli sebagai kepribadian bangsa Indonesia. Selain itu, permainan tradisional mengandung kearifan nilai-nilai filosofi dan nilai-nilai sosial. Ketika anak bermain melalui permainan tradisional, tidak hanya memberi rasa senang, tetapi juga 
mengembangkan fungsi kognitif, psikomotor, sosial dan emosi yang terbentuk karena afiliasi dengan dengan teman sebaya saat bermain menggunakan permainan tradisional.

\section{B. PEMBAHASAN}

\section{Karakteristik Perkembangan Sosial-Emosi Anak AUD}

Masa prasekolah merupakan masa kanak-kanak awal dengan rentang usia 4 6 tahun. Pada usia ini, anak mulai belajar melakukan hubungan sosial dan bergaul diluar lingkungan rumah, terutama dengan anak-anak yang umurnya sebaya. Masa kanak-kanak awal sering di sebut " usia pragang" (pregang age) pada masa ini sejumlah hubungan yang dilakukan anak dengan anak lain meningkat dan ini sebagian menentukan bagaimana gerak maju perkembangan sosial mereka. Anakanak yang mengikuti pendidikan prasekolah melakukan penyesuaian sosial yang lebih baik dibandingkan dengan anak-anak yang tidak mengikuti pendidikan prasekolah (Akman, 2009). Hal ini disebabkan anak-anak dipersiapkan secara lebih baik untuk melakukan partisipasi yang aktif dalam kelompok dibandingkan dengan anak yang aktivitas sosialnya terbatas dengan anggota keluarga dan anak-anak dari lingkungan tetangga terdekat. Keuntungan pendidikan prasekolah adalah memberikan pengalaman sosial dibawah bimbingan guru yang terlatih yang membantu mengembangkan hubungan yang menyenangkan dan berusaha agar anak-anak tidak mendapat perlakuan yang mungkin menyebabkan mereka menghindari hubungan sosial.

Pola prilaku dalam situasi sosial pada masa kanak-kanak awal: kerja sama, persaingan, kemurahan hati, hasrat akan penerimaan sosial, simpati, empati, ketergantungan, sikap ramah, sikap tidak mengasingkan diri sendiri, meniru.

\section{a. Hubungan dengan orang dewasa}

Dengan berkembangnya keinginan terhadap kebebasan, anak-anak mulai melawan otoritas orang dewasa. Jika anak telah memperoleh kepuasaan prilaku kelekatan pada masa kanak-kanak, mereka akan terus berusaha membina hubungan yang bersahabat dengan orang dewasa, terutama anggota keluarga.

\section{b. Hubungan dengan anak lain}

Sebelum usia 2 tahun anak terlibat dalam permainan seorang diri atau searah. Sejak umur 3 atau 4 tahun, anak-anak mulai bermain bersama dengan kelompok, berbicara satu sama lain pada saat bermain, dan memilih dari anak-anak yang hadir siapa yang akan dipilih untuk bermain. Anak-anak usia dini ini biasanya mudah bersosialisasi dengan orang sekitarnya. Umumnya anak usia ini memiliki satu atau dua sahabat, tetapi sahabat ini mudah berganti. Mereka umumnya mudah dan cepat menyesuaikan diri secara sosial. Sahabat yang dipilih biasanya yang memiliki jenis kelamin yang sama, kemudian berkembang kepada jenis kelamin yang berbeda. Kelompok bermain anak usia ini cenderung kecil dan tidak terorganisasi secara baik, oleh karena itu kelompok ini cepat berganti. 
c. Bentuk umum prilaku sosial

Landasan yang diletakkan pada masa kanak-kanak awal akan menentukan cara anak menyesuaikan diri dengan orang lain dan situasi sosial jika lingkungan merekan semakin meluas dan jika mereka tidak mempunyai perlindungan dan bimbingan dari orang tua sejak bayi. Terjadinya peningkatan prilaku sosial akan tergantung pada tiga hal:

1) Seberapa kuat keinginan untuk diterima secara sosial

2) Pengetahuan mereka tentang cara memperbaiki perilaku

3) Kemampuan intelektual yang semakin berkembang dan memungkinkan pemahaman hubungan antara prilaku mereka dengan penerimaan sosial.

Adapun dalam konteks emosi sebagai reaksi yang terorganisasi dan muncul terhadap hal-hal yang berhubungan dengan kebutuhan, tujuan, ketertarikan, dan minat individu, maka emosi pada tahap anak usia dini lebih terperinci dan didefferensiasi dan anak cenderung mengekspresikan emosinya dengan bebas dan terbuka. Karasteristik emosi pada anak usia dini di tandai dengan berbagai ciri, misalnya emosi anak bersifat sementara dan lekas berubah. Jika anak bertengkar dan saling mencaci maki pada pagi atau siang hari, mak pada sore hari terhalang beberapa jam anak sudah berbaikan dan bermain bersama lagi. Berbeda dengan orang dewasa, sekali berseteru akan melekat lama bisa berhari-hari, berbulan-bulan, bertahun-tahun, bahkan mungkin sampai meninggal dunia belum berubahdan masih tetap bersitegang. Ciri lainnya dari perilaku emosional anak ialah reksi kuat dan spontan terhadap situasi yang menimbulkan rasa senang atau tidak senang. Anak akan mengutarakan perasaan, keadaan, dan informasi yang mereka terima apa adanya, tidak ditutup-tutupi. Anak prasekolah cenderung mengekspresikan emosinya dengan bebas dan terbuka. Pada tahapan ini anak sering memperebutkan perhatian guru. Emosi yang tinggi pada umumnya disebabkan oleh masalah psikologis dibanding masalah fisiologi.

\section{Kompetensi Sosial-Emosi Anak AUD}

Kompetensi sosial-emosi anak usia dini menurut Permendiknas No. 58 tahun 2009, untuk usia 4 - 5 tahun diantaranya: 1) Menunjukkan sikap mandiri dalam memilih kegiatan; 2) Mau berbagi; 3) menolong, dan membantu teman; 4) Menunjukan antusiasme dalam melakukan permainan kompetitif secara positif; 5) Mengendalikan perasaan; 6) Menaati aturan yang berlaku dalam suatu permainan; 7) Menunjukkan rasa percaya diri; 8) Menjaga diri sendiri dari lingkungannya; dan 9) Menghargai orang lain.

Sedangkan untuk usia 5 - 6 tahun diantaranya; 1) Bersikap kooperatif dengan teman; 2) Menunjukkan sikap toleran; 3) Mengekspresikan emosi yang sesuai dengan kondisi yang ada (senang-sedih-antusias dsb.); 4) Mengenal tata krama dan sopan santun sesuai dengan nilai sosial budaya setempat; 5) Memahami peraturan dan disiplin; 6) Menunjukkan rasa empati; 7) Memiliki sikap gigih (tidak mudah menyerah); 8) Bangga terhadap hasil karya sendiri; dan 9) Menghargai keunggulan orang lain.

Menurut Stephen (1978, Cartlede \& Milburn, 1993) terdapat empat karakteristik kompetensi sosial-emosi anak berdasarkan model analisis tugas, yaitu : 
a. Perilaku berhubungan dengan diri (self-related behavior) yaitu perilaku sosial yang dimunculkan karena adanya pertimbangan dan penghayatan dalam diri. Beberapa bentuk perilaku ini antara lain: a) perilaku etis, yaitu perbuatan atau aktivitas yang didasarkan pada hal yang baik dan buruk sesuai dengan penerimaan sosial; b) ekspresi perasaan, yaitu ungkapan atau pernyataan perasaan yang dapat terlihat melalui ucapan dan reaksi gerak isyarat yang menjadi ciri khas emosi-emosi; c) sikap positif terhadap diri, yaitu tingkah laku untuk mereaksi keadaan diri dengan menerima kelebihan dan kekurangan yang ada; d) perilaku bertanggung jawab; e) menerima konsekuensi terhadap hal-hal yang telah dilakukan; dan f) merawat diri;

b. Perilaku berhubungan dengan lingkungan (environmental behaviors) perilaku sosial yang dimunculkan karena adanya pengaruh pandangan orang-orang yang ada di sekitar individu sesuai dengan nilai atau norma yang dianut pada lingkungan tertentu. Bentuk perilaku yang didasarkan lingkungan antara lain: a) menjaga dan merawat kebersihan lingkungan; b) sikap saat menghadapi situasi darurat; c) perilaku di ruang makan; dan 4) cara bergaul;

c. Perilaku berhubungan dengan tugas (task-related behaviors) adalah perilaku sosial yang dimunculkan karena adanya tuntutan dan kewajiban yang harus dilakukan untuk mendapatkan penghargaan sosial. Bentuk perilaku yang didasarkan pada tugas antara lain: a) bertanya dan menjawab persoalan/ pertanyaan; b) perilaku memperhatikan; c) aktif dalam diskusi kelas; d) melengkapi tugas; e) kegiatan kelompok atau ekstrakurikuler; dan f) memiliki kualitas belajar yang baik;

d. Perilaku interpersonal (interpersonal behaviors) adalah perilaku sosial yang berlangsung antara dua orang atau lebih yang mencirikan proses-proses yang timbul sebagai satu hasil dari interaksi secara positif. Bentuk perilaku interpersonal antara lain: a) menerima kepemimpinan; b) mengatasi konflik; c) memberi perhatian; d) membantu orang lain; e) memulai percakapan; f) bergaul dengan teman; g) sikap positif kepada orang lain; h) mampu mengorganisasikan kelompok; dan i) menghormati privasi pribadi dan orang lain.

\section{Media Pembelajaran Anak AUD}

Pembelajaran adalah suatu kegiatan yang mencakup kegiatan belajar dan mengajar. Kegiatan pembelajaran dilakukian berdasarkan rencana yang terorganisir secara sistematis yang mencakup tujuan pembelajaran, materi pembelajaran dan kegiatan pembelajaran yang mencakup metode dan media pembelajaran, evaluasi pembelajaran, dan umpan balik pembelajaran. Suatu trencana pembelajaran dan pelaksanaannya perlu memperhatikan hal-halyang terkait dengan belajar bagaimana belajar, belajar bagaimana berpikir, belajar bagaimana melakukan, dan belajar bagaimana bekerja sama dan hidup bersama.

Sejalan dengan perkembangan anak usia dini, maka pembelajaran perlu menekankan pada empat aspek tersebut di atas. Hal tersebut menjadi faktor yang kritis dalam perkembangan anak yang bersangkutan. Oleh sebab itu, pembelajaran yang direncanakan dan dilaksanakan pada lembaga pendidikan anak usia dini yang dilakukan dalam bentuk berbagai kegiatan bermain perlu menekankan pada empat aspek tersebut di atas ditambah dengan aspek-aspek lain, seperti moral, perilaku 
baik sebagai individu, sebagai anggota masyarakat, maupun sebagai makhluk Tuhan sesuasi dengan nilai-nilai keagamaan.

Sifat pertumbuhan dan perkembangan anak usia dini berlangsung secara simultan dan holistik, sehingga pendekatan dan desain, serta pelaksanaan pembelajaran anak tersebut terintegrasi secara terpadu. Di sisi lain, ada hal yang penting yang juga harus diperhatikan oleh pendidik anak usia dini dalam melaksanakan kegiatan belajar mengajar. Hal penting tersebut adalah berkaitan dengan pemilihan media dalam melaksanakan pengajaran bagi anak usia dini. Sukses tidaknya suatu pengajaran bagi anak usia dini di antaranya adalah tergantung bagaimana seorang pendidik (pengajar) menggunakan media pembelajaran.

\section{Permainan Tradisional sebagai Alternatif Media Pengembangan Kompetensi Sosial-Emosi Anak AUD}

Pembelajaran yang menyenangkan bagi anak merupakan suatu perangsang agar anak mampu mengembangkan kemampuan dasarnya. Pembelajaran yang semacam ini memang harus ditunjang dengan media pembelajaran yang menarik pula. Pada hakikatnya seorang anak akan dengan mudah belajar ketika disuguhkan dengan media yang nyata sebab anak belum mampu berfikir secara abstrak. Maka guru membutuhkan penunjang dalam pembelajarannya melalui media permainan tradisional.

Permainan Tradisional sangat cocok bagi media pembelajaran pendidikan anak usia dini. Alasannya, permainan tradisional mengandung banyak unsur manfaat dan persiapan bagi anak menjalani kehidupan bermasyarakat. Beberapa jenis permainan tradisional itu seperti cinciripit, galah bandung, congklak, bebentengan, oray-orayan, boy-boyan mengembangkan aspek pengembangan moral, nilai agama, sosial, emosi, dan fungsi motorik. Oleh karena itu permainan tradisional bisa menjadi sarana yang baik dalam mengembangkan pendidikan anak usia dini.

Permainan edukatif adalah semua bentuk permainan yang dirancang untuk memberikan pengalaman pendidikan atau pengalaman belajar kepada para pemainnya, termasuk Permainan tradisional yang memiliki muatan pendidikan dan pengajaran (Adams, 1975). Atas dasar pengertian itu, permainan yang dirancang untuk memberi informasi atau menanamkan sikap tertentu, misalnya untuk memupuk semangat kebersamaan dan kegotongroyongan, termasuk dalam kategori permainan edukatif karena permainan itu memberikan pengalaman belajar kognitif dan afektif. Permainan tradisional juga dirancang tidak hanya mengedepankan aspek kesenangan, namun memiliki makna yang lebih jauh baik bagi perkembangan sosial maupun emosi anak, sehingga permainan tradisional dapat dikatakan sebagai permainan edukatif.

Permainan tradisional edukatif merupakan suatu kegiatan yang sangat menyenangkan dan dapat merupakan cara atau alat pendidikan yang bersifat mendidik dan bermanfaat untuk meningkatkan kemampuan berbahasa, berpikir serta bergaul dengan lingkungan atau untuk menguatkan dan menterampilkan anggota badan anak, mengembangkan kepribadian, mendekatkan hubungan antara pendidik dengan anak, kemudian menyalurkan kegiatan anak didik dan sebagainya. 
Permainan tradisional yang edukatif juga dapat berarti sebuah bentuk kegiatan yang dilakukan untuk memperoleh kesenangan dari cara atau media pendidikan yang digunakan dalam kegiatan bermain, yang disadari atau tidak, memiliki muatan pendidikan yang dapat bermanfaat dalam mengembangkan diri anak. Artinya, permainan tradisional merupakan sebuah bentuk kegiatan mendidik yang dilakukan dengan menggunakan cara atau media permainan yang bersifat mendidik.

Permainan tradisional penting bagi anak-anak, disebabkan karena:

a. Dapat membantu anak dalam mengembangkan dirinya.

b. Mampu meningkatkan kemampuan berkomunikasi bagi anak.

c. Mampu membantu anak dalam menciptakan hal baru atau memberi inovasi pada suatu permainan.

d. Mampu meningkatkan cara berpikir pada anak.

e. Mampu meningkatkan rasa percaya diri pada anak.

f. Mampu merangsang imajinasi pada anak.

g. Dapat melatih kemampuan bahasa pada anak

h. Dapat membentuk moralitas anak.

i. Dapat mengembangkan sosialisasi pada anak.

Banyak permainan tradisional yang dapat dilakukan anak usia dini untuk meningkatkan perkembangan kognitif, meningkatkan daya jelajah, dan memberikan pengetahuan dasar tentang kehidupan, sosial dan emosi. Selama interaksi dalam permainan anak-anak mempraktekkan peran-peran yang akan anak lakukan pada masa yang akan datang. Anak-anak yang bermain akan mampu melepaskan tekanan sehingga mampu mengatasi masalah dalam kehidupannya. Permainan memungkinkan anak melepaskan energi fisik yang berlebihan dan membebaskan perasaan-perasaan yang terpendam.

Permainan yang ada di bawah ini dapat dijadikan media pembelajaran bagi anak antara lain:

\section{a. Permainan Congklak}

Permainan yang disebut dakon dalam bahasa jawa ini, biasanya di mainkan oleh dua anak perempuan. Permainan congklak menggunakan papan yang disebut papan congklak. Ukuran papan terdiri atas 16 lubang untuk menyimpan biji congklak. Keenambelas lubang tersebut saling berhadapan dan 2 lubang besar dikedua sisinya. Kemudian anak-anak pun membutuhkan 98 biji congklak. Biji congklak yang biasanya di gunakan adalah cangkang kerang, biji-bijian, batu-batuan, kelereng atau plastik. Dua lubang besar tersebut merupakan milik masing-masing pemain untuk menyimpan milik masing-masing pemain untuk menyimpan biji congklak yang di kumpulkannya. Dua lubang tersebut biasanya kosong sedangkan 14 lubang yang lain diisi 7 biji congklak.

Permainan congklak di atas dapat mengembangkan berbagai aspek yang akan di kembangkan pada anak di antaranya yaitu sebagai berikut:

1) Melatih kesabaran dan dan ketelitian (emosi)

Permainan ini sangat memerlukan kesabran dan ketelitian. Terutama saat pemain harus membagikan biji congklak ke dalam lubang-lubang yang ada di depannya. Jika si pemain tidak sabar dan tidak teliti maka pemain tidak akan berjalan 
dengan baik dan pemian yang tidak bermain harus sabar menunggu giliran pemain yang sedang bermain terjatuh

2) Melatih jiwa sportifitas (sosial)

Dalam permainan ini di perlukan kemampuan untuk menerima kekalahan karena permainan ini di lakukan hanya 2 orang saja maka akan terlihat jelas menang atau kalahnya. Kekalahan akan sangat terasa manakala si pemenang akan meninggalkan satu butir biji congklak saja.

3) Menjalin kontak sosialisasi (sosial)

Faktor ini merupakan hal terpenting dalam permainan ini karena di lakukan secara bersama-sama maka akan terjalin suatu kontak sosial antara pemainnya. Berbagai macam informasi dapat di sampaikan saat permainan ini di lakukan tak jarang senda gurau dan tawa terdengar saat permainan ini berlangsung.

b. Permainan Oray-orayan

Oray-orayan merupakan Lagu Permainan Sunda yang dinyanyikan oleh anak-anak yang bermain oray-orayan atau ular-ularan, biasanya sebelum bermain saling memegang pundak teman yang lain yang ada di depannya, kemudian apabila lagu habis maka akan ada satu anak yang diambil. Permainan oray-orayan dapat mengembangkan kerja sama dimana anak mampu berinteraksi dengan teman sebaya ketika memainkan permainan ini, pengendalian diri, keberanian dan percaya diri.

c. Permainan Bebentengan

Permainan ini mengunakan alat bantu bisa berupa batu bata / benda apa saja yang dijadikan bentengnya. Permainan ini membutuhkan peraturan-peraturan tertentu yang disepakati. Setiap kelompok berusaha untuk menjaga benteng dari serangan lawan. Pemenang permainan ini adalah kelompok yang mampu mengambil alih benteng, atau banyaknya sandera dari kelompok lawan. Permainan ini memupuk kekompakan dan kerja sama dimana anak harus membangun tim yang solid, kompak agar memenangi permainan ini, permainan ini juga merangsang solidaritas antar teman dimana teman yang disandera/ ditangkap dapat dibebaskan sehingga anggota kelompok akan berusaha untuk membebaskannya. Permainan ini juga melatih emosi dimana anak akan berusaha mengendalikan diri saat ditangkap oleh kelompok lawan.

\section{d. Permainan Boy-boyan}

Permainan ini menggunakan alat yang bisa didapat di mana saja dan tak perlu mengeluarkan uang untuk mendapatkannya. Seperti pecahan genting yang bisa didapat disekitar rumah atau kaleng susu bekas dan sebuah bola kecil yang empuk (bisa dibuat dari buntalan kertas yang dilapisi plastik). Bolanya harus empuk, karena selain untuk dilempar ke susunan genting yang berbentuk menara, bola ini juga digunakan untuk dilempar ke tubuh pemain. Model permainannya yaitu menyusun lempengan pecahan genting menyerupai menara yang kemudian harus dirubuhkan menggunakan bola dan harus disusun kembali seperti semula. Sebelum bermain boy-boyan, selain harus menyiapkan dua alat tadi kita juga harus membagi peserta menjadi dua tim, misal tim A dan tim B. Setelah itu biasanya kedua tim akan melakukan hompimpa untuk menentukan tim mana yang berhak melempar terlebih dahulu. Tim yang menang akan melempar terlebih dahulu dan 
tim yang kalah kebagian menjaga. Tim yang menang harus melemparkan bola ke arah tumpukan genting, jika tumpukan tersebut berhasil dihancurkan, maka semua anggota tim yang menang harus berlari untuk menghindari lemparan dari tim yang menjaga. Tim yang menang juga harus menyusun kembali menara genting yang hancur sambil menghindari lemparan bola dari tim yang menjaga. Jika tim yang menang berhasil menyusun kembali menaranya sebelum semua tim yang menang terkena lemparan bola, maka mereka jadi pemenangya dan berhak menjadi tim pelempar lagi. Sedangkan tim yang menjaga harus berusaha menggagalkan tim yang menang untuk menyempurnakan tumpukan genting dengan melempar bola ke arah badan semua anggota tim yang menang. Apabila semua anggota tim yang menang terkena lemparan atau gagal menghancurkan tumpukan genting, maka tim yang jaga akan mendapat bagian melempar bola ke arah tumpukan genting. Permainan ini sangat mengasah kerja sama tim dimana setiap tim memerlukan komunikasi satu sama lain, keberanian dan mengontrol diri untuk menentukan kapan harus menyusun kembali menara dan kapan harus berlari.

\section{PENUTUP}

Permainan tradisional dapat menjadi alternatif media untuk mengembangkan kompetensi sosial dan emosi. Terdapat berbagai pilihan permainan yang dapat dimodifikasi sesuai kondisi anak. Nilai-nilai yang terkandung dalam permainan tradisional selain menyenangkan juga mengembangkan sikap membantu teman, mentaati peraturan, menunjukkan rasa percaya diri, kooperatif, tidak menyerah dan mengembangkan jiwa sportivitas. Atas dasar hasil kesimpulan di atas, direkomendasikan dilakukannya eksplorasi dan kompilasi permainan tradisional berbasis budaya lokal yang dapat dimanfaatkan sebagai media pembelajaran untuk mengembangkan komptensi sosial-emosi AUD. Secara yuridis ada baiknya dibuat Pusat Studi khusus yang mewadahi pemanfaatan permainan tradisional untuk kepentingan proses pendidikan (pembelajaran) khususnya dalam rangka mengembangkan komptensi sosial-emosi AUD. Ke depan, diharapkan muncul kesadaran dan wawasan para pendidik khususnya di lingkungan PAUD agar memiliki kemampuan dan dukungan untuk memanfatkan permainan tradisional untuk kepentingan pengembangan kompetensi sosial-emosi AUD secara khsusus dan untuk kepentingan pendidikan lainnya secara umum.

\section{DAFTAR PUSTAKA}

Anthony, L. G., Anthony, B. J., Granville, D. N., Naiman, D. Q., Waanders, C., \& Shaffer, S. (2005). 'The relationships between parenting stress, parenting behavior and preschoolers' social competence and behavior problems in the classroom'. Infant the Child Development. 14: 133-154.

Boushel, M., Fawcatt, M., \& Selwyn, J. (2000). Focus on Early Childhood. Oxford: Blackwell Science.

Bradley, R.T., Atkinson, M., Tomasino, D., \& Rees, R.A. (2009). Facilitating Emotional Self-Regulation in Preschool Childre : Efficacy of the Early Heart Smarts Program in Promoting Social, Emotional and Cognitive Development. Research Report. Institute of Heart Math, USA. 
Cartledge, G., Milburn, J.F. (1995). Teaching Social Skill to Children and Youth. Third Edition. United States of America : Allen and Bacon

Ekinci V. D., \& GLiqimsek, I. (2009). 'Okul oncesi egitimde aile katilimli sosyal beceri egitim' [Social skills training with family involvement in preschool education].

Newsa: E-Journal of New World Sciences Academy, 4(3): 11101122.

Farrel, P. (2005). Children with Emotional and Behavioural Difficulties. London: The Falmer Press.

Giilay, H., \& Akman A. (2009). 'Okul Oncesi donemde sosyal beceriler' [social skills at preschool age]. Ankara: PegemA Press.

Goldstein, Sam. (1995). Understanding and Managing Children's Classroom Behavior. Canada : John Wiley and Sons. Inc.

Goleman, Daniel. (1997). Kecerdasan Emosional. Jakarta : PT Gramedia Pustaka Utama

Graziano, P.A., Reavis, R.D., Keane, S.P. \& Calkins, S.D. (2007). The Role of Emotion Regulation in Children's Early Academic Success. Journal of School Psychology. $45: 3-19$.

Gross, J.J. (2007). Handbook of Emotion Regulation. New York: The Guilford Press.

Holodynski, M. \& Friedlmeier, W. (2006). Development of Emotions and Emotion Regulation. USA: Springer Science +Business Media, Inc.

Horn, M. L. V., Karlin, E. 0., Ramey, S. L., Aldridge J., \& Snyder, S. W. (2005). 'Effects of developmentally appropriate practices on children's development: a review of research and discussion of methodological and analytic issues'. The Elementary School Journal. 105(4): 325-351.

Jersild, A.T. (1962). Psychologi Anak. Edisi Keempat. Alih Bahasa : Mochtar Buchori. Bandung : Tarate

Kaplan, I.H., Sadock, J.B., Grebb, A.J. (1997). Sinopsis Psikiatri : Ilmu Pengetahuan Perilaku, Psikiatri Klinis. Edisi Ketujuh. Jilid Dua. Jakarta : Binarupa Aksara

Kemp, C., \& Carter, M. (2005). 'Identifying skills for promoting successful inclusion in kindergarten'. Journal of Intellectual \& Developmental Disability, 30(1): 3144 .

Matson, Jhonny L \& Thomas H. Ollendick. (1988). Enhancing Children's Social Skill: Assessment and Training. New York: Pergamon Press.

Mu'tadin, Zainun. 2002. Mengembangkan Keterampilan Sosial pada Remaja. http:/ / www. e-psikologi.com.25/4/04

Nezlek, J.B. \& Peter Kuppens, P. (2008). Regulating Positive and Negative Emotions in Daily Life. Journal of Personality. $76: 3$.

Papalia, D.E., Old, S.W. \& Feldman, R.D. (2008). Perkembangan Manusia. Jakarta: Salemba Humanika.

Philippot, P. \& Feldman, R.S. (2004). The Regulation of Emotion. New Jersey: Lawrence Erlbaum Associates.

Sabri, M.A. (1993). Pengantar Psikologi Umum dan Perkembangan. Jakarta : Pedoman Ilmu Jaya.

Santrock, J.W. (2010). Psikologi Pendidikan. Jakarta: Kencana.

Santrock, W.J. (2002). Life Span Development : Perkembangan Masa Hidup. Edisi Kelima. Jakarta : Erlangga 
Taylor, L. (2005). Introducing Cognitive Development. USA: Psychology Press Taylor \& Francis Group.

Yulianty, Rani. (2010). Permainan yang meningkatkan kecerdasan anak dalam modern dan tradisisonal. Jakarta: Laskar Aksara. 